\section{Pacific Halibut}

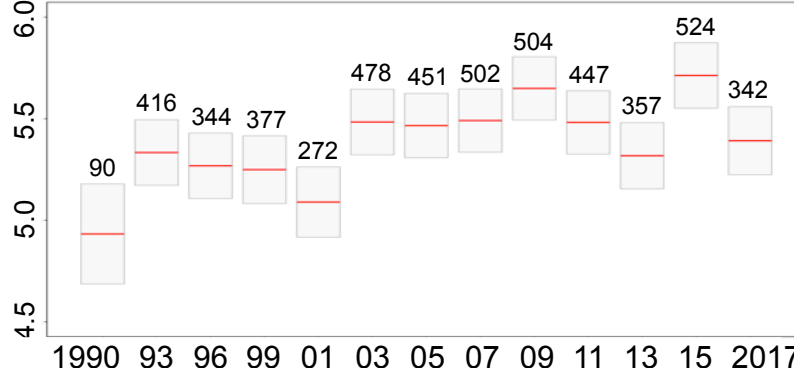

$\begin{array}{lllllllllllll}1990 & 93 & 96 & 99 & 01 & 03 & 05 & 07 & 09 & 11 & 13 & 15 & 2017\end{array}$ Survey Year
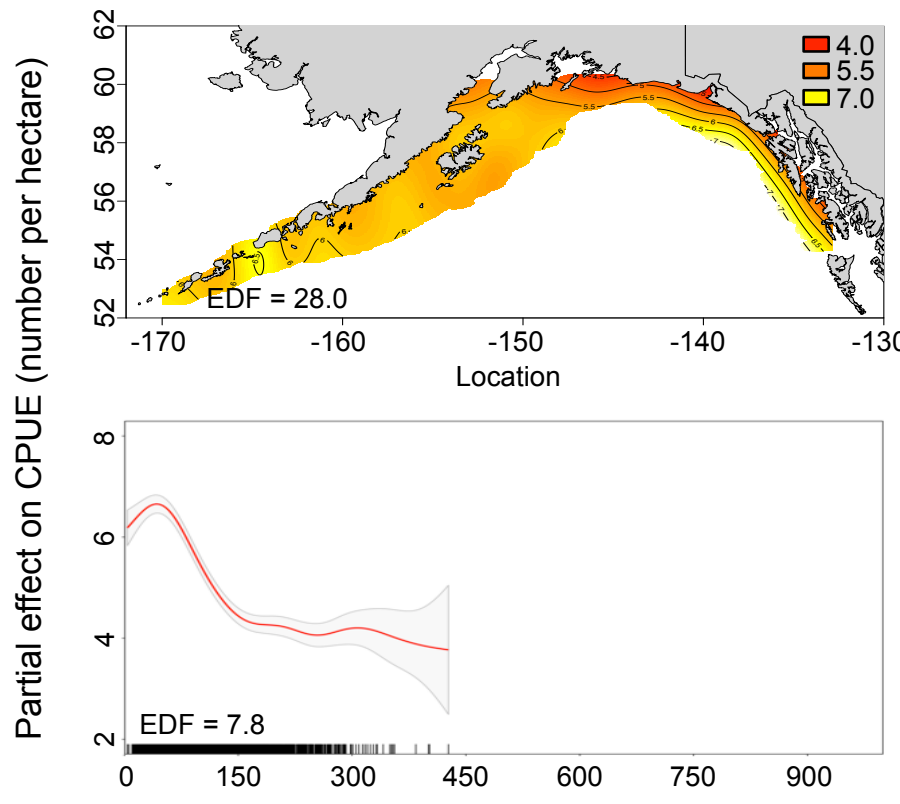

Depth $(\mathrm{m})$

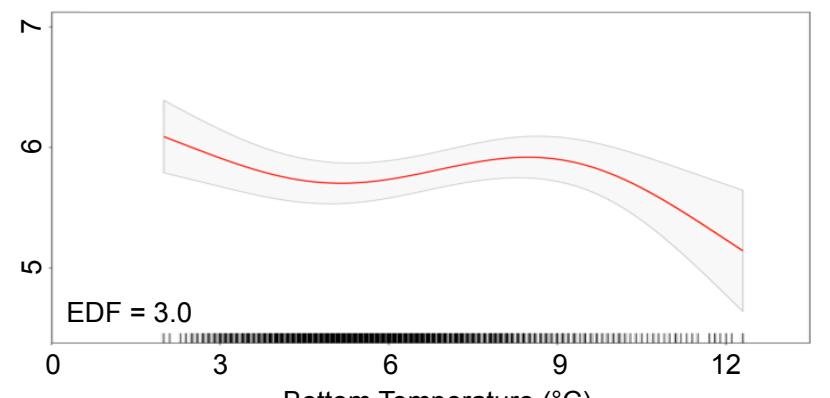

Bottom Temperature $\left({ }^{\circ} \mathrm{C}\right)$
Arrowtooth Flounder

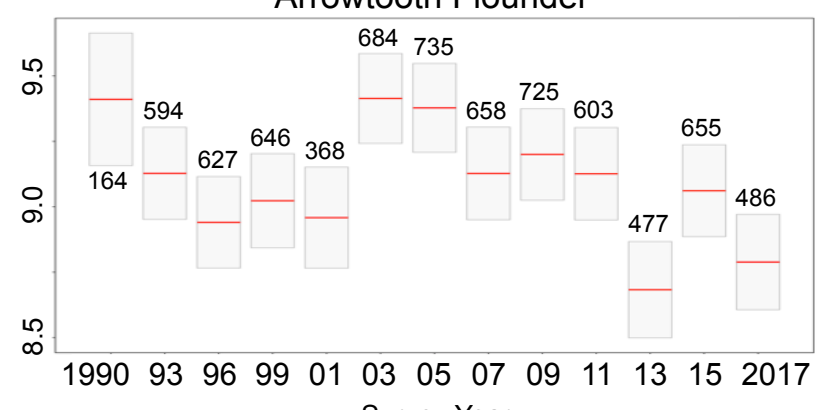
Survey Year
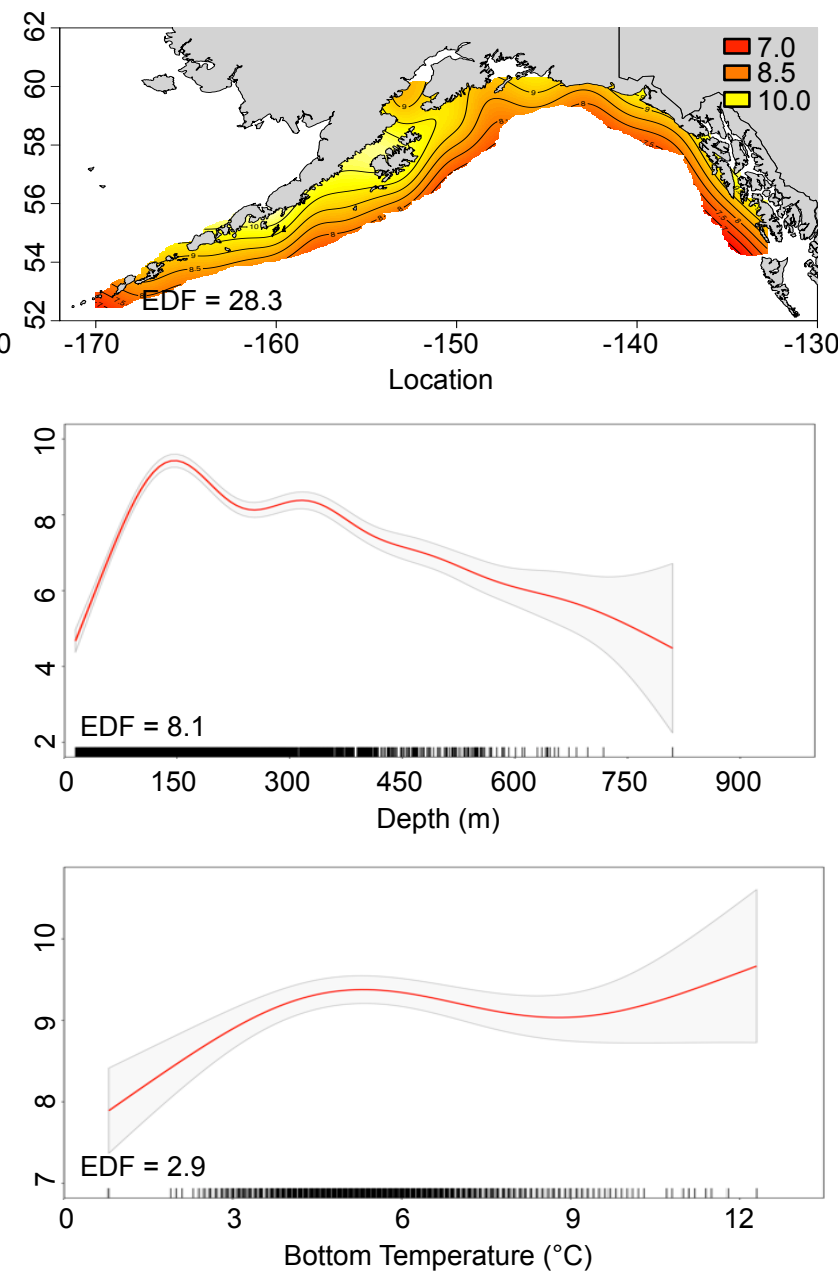